\title{
RET Rearrangement Testing Method
}

National Cancer Institute

\section{Source}

National Cancer Institute. RET Rearrangement Testing Method. NCI Thesaurus. Code C158950.

A request to enter the specific molecular analysis method used to detect and identify rearrangements involving the RET gene. 